ГРНТИ 10.15, 10.31, 10.33, 10.79

DOI: 10.14451/2.150.30

\title{
СУЩНОСТЬ СУДОПРОИЗВОДСТВА В ФОКУСЕ КОНЦЕПЦИИ СУДЕБНОГО ПРАВА *
}

\author{
(ㄷ) 2020 Соколов Тимур Викторович \\ кандидат юридических наук, старший научный сотрудник \\ Государственный академический университет гуманитарных наук (ГАУГН), Россия, Москва \\ E-mail:tvs_2008@mail.ru
}

Возрождение в настоящее время концепции судебного права ставит перед отраслевыми науками задачу согласования своих теоретических подходов к решению основных вопросов. В статье представлен основанный на концепции судебного права подход к раскрытию сущности судопроизводства как механизма реализации судебной власти, подчиняющегося определенным требованиям по обеспечению справедливости судебного разбирательства.

Ключевые слова: судебная власть; правосудие; судопроизводство; судебный контроль; судебное право; конщепция судебного права.

\section{Введение}

В юридической науке есть термины и понятия, смысл которых, на первый взгляд, очевиден если не всем, то очень многим юристам. Нередко такие понятия воспринимаются как аксиомы или азбучные истины. В ряду этих вопросов есть и те, что носят, на первый взгляд, терминологический характер, однако при более внимательном приближении он носят важный, буквально принципиальный характер: от решения данных вопросов зависит решение множества частных вопросов и (или) прикладных проблем. Вместе с тем, различные научные школы могут придерживаться разных подходов к пониманию одних и тех же терминов, а не совсем удачные контексты словоупотребления - открывать новые грани для характеристики обозначаемого тем или иным термином явления.

Задача, образно названная еще Конфуцием «исправлением имен», актуальна сама по себе, однако приобретает всё большее значение в условиях развития новых научных подходов. Возрождающаяся в настоящее время концепция судебного права ставит множество вопросов сопряжения (согласования) существующего научного знания с новым знанием, предлагаемым концепцией судебного права. Одним из первых вопросов, который надлежит решить данной возрождающейся концепции, является вопрос сущности судопроизводства.
1. Судебная власть и судопроизводство: сложившиеся российские доктринальные подходы

Искомый подход к выявлению сущности судопроизводства следует искать в его связи с первой, фундаментальной категорией судебного права - категорией «судебная власть».

Рассматривая внешние характеристики судопроизводство, следует отметить, что оно является механизмом, средством либо формой реализации судебной власти [1, с. 31 ; 2, с. 209, 535]. Это со всей очевидностью вытекает из статьи 118 (часть 2) Конституции Российской Федерации, согласно которой судебная власть осуществляется посредством конституционного, гражданского, административного и уголовного судопроизводств. В ходе конституционной реформы 2020 года этот перечень дополнен арбитражным судопроизводством, что еще раз обратило внимание к дискуссии о природе арбитражного процесса и основаниях для его претензий на статус самостоятельного вида судопроизводства.

Между тем, такое понимание судопроизводства также требует уточнения, поскольку взаимосвязь судебной власти и судопроизводства в российской литературе понимается по-разному, что убедительно демонстрирует развернувшаяся в начале 2000-х гг. научная дискуссия о формах, функциях, методах и механизмах реализации судебной власти.

\footnotetext{
* Статья подготовлена в Государственном академическом университете гуманитарных наук в рамках государственного задания Министерства науки и высшего образования Российской Федерации (тема № FZNF-20200014 «Современное информационное общество и цифровая наука: когнитивные, экономические, политические и правовые аспекты».
} 
Проблеме сущности судебной власти (скорее, формулированию ее дефиниции) весьма много уделено внимания в научной литературе: обзор подходов и точек зрения по этому вопросу приведен, например, С. К. Загайновой [3, с. 18-23]. Поэтому не затрагивая особым образом вопроса о сущности самой судебной власти, следует отметить, что в учебной литературе распространена точка зрения, согласно которой формами осуществления судебной власти являются правосудие, конституционный контроль, судебный контроль за законностью и обоснованностью решений и действий органов, осуществляющих оперативно-розыскную деятельность, дознание и предварительное следствие, обеспечение исполнения судебных решений, разъяснение действующего законодательства по вопросам судебной практики, участие в формировании судейского корпуса и содействие органам судебного сообщества [4, с. 45].

По мнению В.А.Ржевского и Н. М. Чепурновой, формами осуществления судебной власти являются: правосудие, надзор за судебной деятельностью, судебное управление, судебный контроль за исполнительной властью, судебный конституционный контроль [5, с. 96-68]. В то же время правосудие рассматривается и как функция судебной власти, наряду с которой существуют иные функции. Так, И.С. Масликов в теории государства и права [6, с. 10-11], Е.Б.Абросимова, Г.А. Гаджиев, Е.А. Дюкова в науке конституционного права $[7$, с. 10,14 ; 8, с. 10; 9, с. 11], С.А.Шейфер и В.А.Яблоков, В.А.Азаров и И.Ю.Таричко в уголовном процессе $[10$, с. $198 ; 11$, с. $32 ; 12$, с. 12] и А.Ф.Изварина и А. В.Цихоцкий в рамках гражданского процесса [13; 14, с. 32] - рассматривают в качестве основных функций судебной власти только правосудие и судебный контроль, в связи с чем заслуживает обсуждения точка зрения о том, что функцией судебной власти наряду с правосудием является судебный конституционный контроль: получается, что конституционный контроль, осуществляемый конституционными судами в процессуальной форме конституционного судопроизводства чем-то (вопрос чем?) сущностно отличается от правосудия, вполне спокойно бытующего в других, отраслевых или народных видах судопроизводства.

С.К.Загайнова выделяет у судебной вла- сти наряду с правосудием, как внешней функцией судебной власти, ее внутрисистемную функцию - судебное управление, состоящее в обеспечении единства судебной практики процессуальными средствами, издание Пленумом Верховного Суда и Пленумом Высшего Арбитражного Суда Российской Федерации постановлений по вопросам судебной практики, а также организационное руководство деятельностью судов [3, с. 53-57].

В.В.Скитович же рассматривает правосудие, юрисдикционный (судебный) контроль, формирование судейского корпуса и руководство судебной практикой не как формы осуществления, а как функции судебной власти [15, с. 150].

Другие ученые отрицали такие широкие подходы, полагая, что судебная власть может осуществляться посредством единственно возможной формы реализации - правосудия. И.Б. Михайловская полагает, что основной функцией судебной власти является судопроизводство, поскольку ее социальное назначение реализуется только в форме судопроизводства; также она отождествляет понятия судопроизводства и правосудия [16, с. 22-24].

Любая властная деятельность суда (собственно реализация судебной власти) отвечает признакам правосудия. При этом содержание понятия правосудия в российской правовой системе рассматривается максимально широко. По мнению В.А.Лазаревой, «единой функцией судебной власти является разрешение социальноправовых конфликтов, защита и восстановление нарушенных прав», «единой формой реализации судебной власти - правосудие», а «методами (способами) его осуществления - различные виды судопроизводства: конституционное, гражданское (включая арбитражное), административное и уголовное» [17, с. 16; 18, с. 32; 19, с. 30].

Очевидно, что в литературе - при полном молчании отраслевого законодателя по данному вопросу - отсутствует научная определенность, вследствие чего под одними и теми же терминами могут скрываться различные правовые явления, а потому представляется актуальной задача упорядочения категориального аппарата учения о судебной власти, что возможно осуществить на методологической основе концепции судебного права. 
2. Судопроизводство как механизм реализации судебной власти: подходы в рамках концепции судебного права

Категориальный аппарат концепции судебного права должен быть универсален для всех юридических наук, т.е. носить общеправовой характер; иначе - в ситуации существования в различных научных дисциплинах процессуального права разнообразных определений и подходов к исследованию одних и тех же явлений - терминологическая функция концепция судебного права остается не реализованной, что нельзя расценивать позитивно.

По нашему мнению, в рамках концепции судебного права следует полагать, что судебная власть реализуется посредством четырех видов судопроизводства - конституционного, гражданского, административного и уголовного, а правосудие является единственной формой осуществления судебной властью своих полномочий; правосудие может пониматься в узком и широком смыслах: в узком - только как совокупность действий суда в судопроизводстве, в широком - как совокупность деятельности и суда, и иных участников судопроизводства во всех видах судопроизводства.

Судебный контроль не должен выделяться в доктрине в качестве самостоятельной формой реализации судебной власти или же функцией суда в процессе, он представляет собой лишь цель деятельности суда в конкретном процессуальном производстве, осуществляемом - независимо от стадии процесса - в форме правосудия. Данные суждения, безусловно, требуют дополнительного обоснования, но в силу предмета данной работы остаются за ее пределами. Между тем, об осуществлении судом полномочий по так называемому судебному контролю в форме правосудия справедливо говорится в актах высших судебных инстанций: см., напр.: пункт 1 постановления Пленума Верховного Суда Российской Федерации от 10 февраля 2009 года № 1 «О практике рассмотрения судами жалоб в порядке статьи 125 Уголовно-процессуального кодекса Российской Федерации» (Российская газета. 2009. № 27 (18 февраля); пункт 2 постановления Пленума Верховного Суда Российской Федерации от 20 декабря 2011 года № 21 «О практике применения судами законодательства об исполнении приговора» (Российская газета. 2011. № 296 (30 декабря)), а также Постановление Пленума Вер- ховного Суда Российской Федерации от 31 мая 2007 года № 2 «О практике рассмотрения судами дел об оспаривании решений квалификационных коллегий судей о привлечении судей судов общей юрисдикции к дисциплинарной ответственности» (Российская газета. 2007. № 122 (8 июня); 2010. № 115 (28 мая)).

Поэтому следует согласиться с теми авторами, кто отождествляет правосудие и судопроизводство как средства или формы реализации судебной власти.

2.1. Исходным посылом в решении вопроса о реализации судебной власти применительно к сущности судопроизводства должно быть точное определение категории, через которую раскрывается суть реализации судебной власти. На первый план нужно ставить вопрос не о формах или средствах реализации судебной власти, а о механизме реализации судебной власти посредством различных видов судопроизводства, что ранее было предпринято Л.А. Воскобитовой [20]. Понятия «форма» или «средство» для характеристики реализации судебной власти представляются непригодными.

С одной стороны, в философии данные категории трактуются различным образом, а потому вызывают и будут вызывать разнообразные трактовки в юридической науке. С другой же стороны эти категории несколько «односложны», в то время, когда правосудие (процессуальный компонент) явление разностороннее и сложно организованное, о чем свидетельствует хотя бы лишь количество процессуальных норм. Поскольку судебная власть порождена правом и существует для применения права и только в правовой форме, то приемлемым и плодотворным будет использование термина «механизм реализации судебной власти», рассматриваемым как разновидность механизма правового регулирования применительно к сфере правосудия.

2.2. Вторым посылом к решению интересующего нас вопроса является различение и разграничение процессуального и организационного в реализации судебной власти: если процессуальный компонент представляет собой собственно правосудие, т.е. реализацию судебной власти в собственном смысле, то организационный компонент носит вспомогательный характер по отношению к процессуальному. Совершение судоустройственных действий (в широком смысле - организационных), направленных на 
функционирование надлежащим образом организованных судов, независимых и беспристрастных судей: без должным образом организованного суда требования справедливого правосудия, требуемого статьей 6 Конвенции о защите прав человека и основных свобод, выполнить практически невозможно. Отсюда вытекает неразрывная связь между судоустройством и процессуальным правом, на которую неоднократно обращалось внимание в научной литературе [21;22].

Следовательно, судоустройство есть лишь предпосылка к запуску механизма реализации судебной власти, но в сам механизм элементы судоустройства не входят. Отсюда включение в число форм реализации судебной власти таких правовых институтов организационного порядка, как судебное управление, обобщение судебной практики и др., предлагаемое в литературе многими авторами, с позиции концепции судебного права представляется неверным.

2.3. Механизм реализации судебной власти посредством судопроизводства в рамках категориального аппарата концепции судебного права должен быть универсален, т.е. пригоден и реализуем для всех видов судопроизводства. Однозначного мнения по вопросу структуры или содержания не сложилось. Так, в науке уголовного процесса механизм реализации судебной власти посредством уголовного судопроизводства предложен Л.А.Воскобитовой, в гражданском процессе - С. К. Загайновой и С. Л. Дегтяревым.

Л.А.Воскобитова определяет механизм реализации судебной власти как структурно организованную совокупность процессуальноправовых средств и способов, а также определенную последовательность осуществления судебно-властных отношений при производстве по делу, и выделяет в этом механизме следующие этапы: обеспечение доступа к правосудию, познание фактических обстоятельств дела или иного правового вопроса и разрешение спора и внутрисистемный и внесистемный контроль законности и справедливости осуществления судебной власти и правосудности ее решений [20, с. 14, 19-33].

С. К. Загайнова полагает, что существует два последовательно существующих механизма механизм судебной защиты субъективного материального права, состоящий из обращения в суд, надлежащего рассмотрения и разрешения дела и вынесения и вступления в законную силу судебного акта, и механизм обеспечения судебной защитой посредством исполнения судебных актов [3, с. 83-86; 23].

С.Л.Дегтярев связывает структуру механизма реализации судебной власти с динамикой развития правового конфликта и выделяет следующие этапы: развитие конфликтной ситуации, реализация нормы права, действия суда по осуществлению правосудия на любом из предыдущих этапов [24, с. 286-302; 25].

Очевидно, что данные механизмы различны по структуре, однако и в этом вопросе в науке должна присутствовать определенность. Конструируя механизм реализации судебной власти, следует учитывать, что судопроизводство является одной из форм реализации права, а потому в нем должны находить свое выражение элементы применения права. Отсюда наиболее близким и отвечающим данной идее является подход, предложенный Л.А. Воскобитовой: с одной стороны, он отражает элементы правоприменения (обращение в суд и познание судом фактических обстоятельств дела), а с другой учитывает специфику судебной власти, состоящую во внутрисистемном контроле качества правосудия.

Подход, предложенный С.К.Загайновой, думается, искусственно разделен на две части, причем из-за второй части может сложиться ошибочное мнение, что на судебную власть косвенно, но ложится обязанность по обеспечению исполнения собственного же решения, в то время как эта обязанность в Российской Федерации лежит на органах принудительного исполнения судебных актов и органах уголовноисполнительной системы (Федеральной службе судебных приставов, Федеральной службе исполнения наказания) - федеральных органах исполнительной, а не судебной, власти. Участие же суда в исполнении судебных актов носит иной характер, отличный от разрешения дела по существу [26, с. 110-121].

Построение механизма реализации судебной власти на основе положений науки конфликтологии, предпринятое С.Л.Дегтяревым, также вызывает вопросы и неудобства: связывание судебной деятельности исключительно с разрешением правовых конфликтов представляется методологически не верным, поскольку такой подход не принимает во внимание ситуа- 
цию бесспорных производств (например, особое производство в гражданском процессе); ссылка автора на то, что под правовым конфликтом он понимает «состояние лица, когда оно без помощи органов судебной власти не может реализовать свои права и свободы» [24, с. 60], формально снимает данное замечание, однако исследуемые им положения науки конфликтологии, на которых и строится предлагаемый автором механизм реализации судебной власти, всё же не учитывают данных бесспорных ситуаций, когда спора о праве не существует, а судебная власть тем не менее реализуется и выполняет свои конституционные задачи по обеспечению прав и свобод человека и гражданина, определенное статьей 18 Конституции Российской Федерации.

Таким образом, механизм реализации судебной власти посредством судопроизводства включает в себя, как минимум, следующие этапы:

1) доступ к правосудию (обращение за судебной защитой);

2) познание судом юридически значимых обстоятельств дела и принятие судом решения;

3) контроль правосудности судебного решения.

Данный механизм вполне согласуется с основными стадиями судопроизводства, которые могут быть обнаружены во всех видах судопроизводства.

2.4. Описанный выше механизм реализации судебной власти является универсальным, т.е. применим во всех четырех видах судопроизводства, поскольку судебная власть во всех видах судопроизводства равно подчинена одним и тем же конституционным нормам, направлена на достижение конституционного назначения судебной власти (статья 18 Конституции Российской Федерации) и пользуется в различных видах судопроизводства одним и тем же инструментарием. Между тем, данный механизм в конкретном виде судопроизводства модифицируется в зависимости от характера тех материальных правоотношений, которые стали предметом рассмотрения в конкретном деле. Значит, какие-либо элементы данного механизма приобретают большее значение (выходят на первый план), а другие - наоборот, уходят на второй план. Эта же идея лежит в основе деления судопроизводства на виды, определенного в статье 118 (часть 2) Конституции Российской
Федерации.

Уголовный процесс отвечает структуре механизма реализации судебной власти реализации судебной власти в полной мере, что неоспоримо подтверждает исследование Л.А. Воскобитовой [20], а также многих других авторов. Гражданское, арбитражное и административное, имея несколько отличное от уголовного процесса деление на стадии, тем не менее вполне отражает подчинение идее структуры этого механизма реализации судебной власти.

Что же касается конституционного судопроизводства, то здесь необходимы дополнительные уточнения. Первый и второй этапы реализации судебной власти в данном виде судопроизводства неоспоримо присутствуют; вопросы может вызвать отсутствие третьего этапа - контроля за правосудностью судебных решений.

Решения Конституционного Суда обжалованию и пересмотру не подлежат (статья 79 Федерального конституционного закона от 21 июля 1994 г. № 1-ФК3 «О Конституционном Суде Российской Федерации»), а потому есть основания к утверждению, что контроль правосудности решений конституционных судов не осуществляется. Однако это утверждение не является верным и требует уточнения, объясняющего отсутствие механизма пересмотра решений Конституционного Суда.

Наличие второй и последующих судебных инстанций в традиционных видах судопроизводства объясняется потребностью проверки правильности и законности установления фактических обстоятельств рассмотренного дела и необходимостью контроля в толковании и применения норм материального права, разрешающего дело по существу. В силу этих причин предметом контроля вышестоящих инстанций являются как вопросы факта и вопросы права (классическая апелляция) либо только вопросы права (кассационная и надзорная инстанции в российском правосудии). Предметом же исследования в конституционном судебном процессе по делам о нормоконтроле являются исключительно нормы права, конституционность которых подвергается сомнению. Решить же вопрос конституционности отраслевой нормы права в рамках системы централизованного конституционного контроля, которая имеет место быть в России, можно и в рамках производства в одной инстанции. Судебная ошибка в решении дан- 
ного вопроса устраняется, как видится самой процессуальной формой производства в Конституционном Суде, позволяющей максимально полно и подробно изучить все аспекты рассматриваемого вопроса.

Между тем, более внимательное изучение вопроса показывает, что «вторая» инстанция так или иначе уже фактически присутствует в сфере конституционного правосудия, правда на региональном уровне: конституционно-судебное законодательство ряда субъектов прямо предусматривает пересмотр решений местных конституционных судов. Такие нормы в том или иначе виде знает законодательство о конституционных и уставных судах Республики Бурятия, Республики Башкортостан, Республики Северная Осетия-Алания, Республики Татарстан, Республики Дагестан, Республики Саха (Якутия), а также Иркутской, Свердловской и Челябинской областей. Данные законодательные нормы отражают то, что конституционно-судебному законодательству уже известны механизмы пересмотра решений конституционных судов, отражающие давно известно процессуальной доктрине основания - судебные ошибки в применении процессуального права. Упразднение конституционных (уставных) судов субъектов Российской Федерации в соответствии с Федеральным конституционным законом от 8 декабря 2020 г. № 7-ФКЗ «О внесении изменений в отдельные федеральные конституционные законы», на первый взгляд, выводит этот аспект из поля зрения ученых, однако опыт региональной конституционной юстиции всё же еще рано забывать, а потому он должен сохранить свой потенциал для юридической науки и законодателя.

Конституционное правосудие в целом отвечает предложенному в литературе механизму реализации судебной власти, несмотря на то, что остается определенное поле для совершенствования процессуальной формы конституционного судопроизводства.

2.5. Сущность судопроизводства можно вывести и иным путем, помимо использования формальных характеристик механизма реализации судебной власти. Доктрина судебного права должна иметь некое «среднее взвешенное» понятие суда, по которому деятельность конкретного юрисдикционного органа будет оцениваться как правосудие, деятельность всех участников этого процесса - как судопроизводство. Такой «стандарт правосудия», «общее ме- рило» уже выработано в практике Европейского Суда по правам человека на основе казуального толкования и применения Конвенции о защите прав человека и основных свобод. Понятие «суд», как указывает Т.В.Трубникова, в понимании Европейского Суда по правам человека - это юрисдикционный орган, решающий вопросы, отнесенные к его компетенции на основе норм права, в соответствии с установленной процедурой; при определении факта нарушения статьи 6 Конвенции ЕСПЧ опирается не на название органа, а на следующие критерии:

(1) в компетенцию суда должно входить рассмотрение как вопросов права, так и вопросов факта;

(2) суд должен принимать обязывающие решения, которые не могут быть изменены несудебными властями;

(3) законный характер суда;

(4) независимость органа как по отношению к исполнительной власти, так и по отношению к сторонам процесса;

(5) продолжительность мандата членов суда;

(6) гарантии судебной процедуры;

(7) внешние атрибуты независимости суда [27, c. $76-88]$.

Практика применения статьи 6 Конвенции о защите прав человека и основных свобод выделила институциональные и процессуальные аспекты реализации права на справедливое судебное разбирательство: к числу первых относятся независимость, беспристрастность, компетентность суда, его формирование в соответствии с законом; к числу вторых - собственно справедливость разбирательства, публичность (т.е. гласность), процессуальное равноправие сторон, разумный срок рассмотрения дела [28, с. 36].

Проецируя европейские требования на современное российское правосудие, на его отдельные виды судопроизводства, можно заметить, что они им все же в целом отвечают: правовое регулирование, составляющее процессуальные формы российских видов судопроизводства, с попеременным успехом в целом соответствует европейским требованиям, хотя практика их применения, еще требует своего совершенствования. Вместе с тем, в контексте нашего исследования важно то, что набор требований, выдвигаемых в европейском правопорядке, одинаково применим во всех видах судопроизводства. 


\section{Заключение}

Проведенное исследование показало несколько важных для доктрины процессуального права выводов. Во-первых, российская юридическая наука имеет богатый арсенал теоретических положений, на основе которых могут быть построены рассуждения в рамках концепции судебного права, и вопрос сущности судопроизводства здесь не исключение. Между тем, данные доктринальные положения получены в различных науках процессуального права. а потому они нуждаются в упорядочении и согласовании между собой. Выполнить эту функцию упорядочения и согласования как раз может концепция судебного права. Решение же этих этой задачи на основе концепции судебного права позволяет показать востребованность данной концепции для современной российской юридической науки.

Во-вторых, обоснованный в статье подход к пониманию сущности судопроизводства как механизма реализации судебной власти является тем доктринальным инструментом, который позволяет обнаружить в различных видах судопроизводства концептуальные основания их единства.

В-третьих, подход к раскрытию сущности судопроизводства как механизма реализации судебной власти вполне может выступить основой для унификации видов судопроизводства одной из ключевых задач концепции судебного права. Для унификации видов судопроизводства важно иметь теоретические основания, показывающие всё то общее, что объединяет виды судопроизводства, а не различает их. Структура механизма реализации судебной власти в соответствующих видах судопроизводства как раз является одной из тех теоретических конструкций, которые обеспечивают такое сравнение и в конечном счете - объединение видов судопроизводства он теоретической основе концепции судебного права.

\section{Библиографический список}

1. Изварина А. Ф. Судебная власть в Российской Федерации: учебное пособие. - 2-е изд.- Ростов н/Д: Феникс, 2001.

2. Процессуальное право: Энциклопедический словарь.-М.: Норма, 2003.

3. Загайнова С.К. Судебные акты в механизме реализации судебной власти в гражданском и арбитражном процессе.-М.: Волтерс Клувер, 2007.

4. Гуценко К.Ф., Ковалев М.А. Правоохранительные органы: Учебник для юридических вузов и факультетов.М.: Зерцало, 1998.

5. Ржевский В.А., Чепурнова Н.М. Судебная власть. Конституционные основы организации и деятельности.М.: Юристъ, 1998.

6. Масликов И. С. Судебная власть в государственном механизме Российской Федерации / 12.00.01: автореф. дис. ... канд. юрид. наук. - М., 1997.

7. Абросимова Е.Б. Судебная власть: конституционно-правовые аспекты: Автореф. дис. ... канд. юрид. наук / 12.00.02.- M., 1991.

8. Самостоятельность и независимость судебной власти в Российской Федерации: монография / Под ред. В. В.Ершова.- М.: Юристъ, 2006.

9. Дюкова Е.А. Конституционно-правовые основы контрольной деятельности судебной власти Российской Федерации: автореф. дис. ... канд. юрид. наук / 12.00.02.- М., 2008.

10. Шейфер С.А., Яблоков В. А. Понятие судебной власти и ее функции // Проблемы судебно-правовой реформы в России. История и современность: сб. науч. статей.- Самара, 1999.

11. Азаров В.А., Таричко И. Ю. Функция судебного контроля в истории, теории и практике уголовного процесса России: монография.- Омск: Омск. гос. ун-т, 2004.

12. Таричко И. Ю. Функция судебного контроля в российском уголовном процессе: автореф. дис. ... канд. юрид. наук / 12.00.09.- Омск, 2004. - С. 12.

13. Изварина А.Ф. К вопросу о функциях судебной власти // Вестник Арбитражного суда города Москвы. 2009. № 4 (23). C. 13-17;

14. Цихоцкий А.В. Теоретические проблемы эффективности правосудия по гражданским делам.- Новосибирск: Наука, 1997.

15. Скитович В. В. Судебная власть как системное образование // Правоведение. 1997. № 1 . 
16. Судебная власть в системе разделения властей // Судебная власть: монография / Под ред. И.Л. Петрухина. М.: ООО «ТК Велби», 2003.

17. Лазарева В.А. Судебная защита в уголовном процессе РФ: автореф. дис. ... д-ра юрид. наук / 12.00.09.- М., 2000.

18. Лазарева В.А. Судебная власть и ее реализация в уголовном процессе: учебное пособие.- Самара: Изд-во «Самарский университет», 1999.

19. Лазарева В.А. Судебная власть. Судебная защита. Судебный контроль: понятие и соотношение: лекцииочерки.- Самара: Самарская гуманитарная академия, 1999.

20. Вокобитова Л. А. Механизм реализации судебной власти посредством уголовного судопроизводства: автореф. дис. ... д-ра юрид. наук / 12.00.09.- М., 2004.

21. Полянский Н. Н. Вопросы систематики в уголовном процессе // Советское государство и право. 1939. № 3. С. 71-87.

22. Жуйков В.М. Общая концепция развития процессуального законодательства и законодательства о судоустройстве // Журнал российского права. 2010. № 7. С. 5-17.

23. Загайнова С.К. О структуре механизма реализации судебной власти в гражданском и арбитражном процессах // Арбитражный и гражданский процесс. 2007. № 2. С. 17-19.

24. Дегтярев С. Л. Реализация судебной власти в гражданском судопроизводстве: теоретико-прикладные проблемы.-М.: Волтерс Клувер, 2007.

25. Дегтярев С.Л. Некоторые элементы механизма реализации судебной власти в гражданском судопроизводстве // Проблемные вопросы гражданского и арбитражного процесса / Под ред. Л. Ф. Лесницкой, М.А. Рожковой.-М.: Статут, 2008. С. 26-56.

26. Малешин Д. Я. Исполнительное производство (функции суда): монография.- М.: Городец-издат, 2003.

27. Трубникова Т.В. Право на справедливое судебное разбирательство: правовые позиции Европейского Суда по правам человека и их реализация в уголовном процессе Российской Федерации: учебное пособие.Томск: Изд-во Том. ун-та, 2011.

28. Стандарты справедливого правосудия (международные и национальные практики) / Под ред. Т. Г. Морщаковой.-М.: Мысль, 2012. 